\title{
CORRUPTION, SOCIAL VIOLENCE AND ETHICAL CULTURE IN
} NIGERIA

\section{ABSTRACT}

Ani Kelechi Johnmary Federal University Ndufu-Alike, Nigeria E-mail: johnezekaycee@yahoo.com

Submission: $17 / 02 / 2014$ Revision: 28/02/2014 Accept: 14/03/2014

Corruption is the direct or indirect act of violence aimed at exploiting unmerited gain and or advantage from a person, structure, institution or environment. In Nigeria, corruption has grown to an unquantifiable level. The major causes of corruption include absence of political will, progressive suppression of the culture of accountability, geometric societal poverty and negative socio-economic conditions as well as greed and the get-rich-quick syndrome etc. The paper presents the multi-dimensional phases of corruption in Nigeria and the salient mandate of the Code of Conduct Bureau and Tribunal Act, Economic and Financial Crimes Commission (EFCC) as well as Independent Corrupt Practices and Other Related Offences Commission (ICPC). Unfortunately, the work, which adopted a theoretical approach reveal that the effectiveness of the above institutions and other corruptionwatchdog setups has being watered-down by the negative push and pull effects of what is popularly known as the 'Nigerian factor'. Finally, it argues that the most dangerous implications of corruption are the recurrence of social violence and the near-total collapse of ethical culture in every sector of the Nigerian national life, while recommending multidimensional transformative cultures of corruption management that must be collectively championed by the citizenry.

Keywords: Corruption; Nigeria; Social violence; ethical culture. 
DOI: 10.14807/ijmp.v5i3.198

\section{INTRODUCTION}

Corruption is traceable to the Latin word, corrupts meaning to destroy. It is not a rare phenomenon as it takes many forms with different types of participants, settings, stakes, techniques and different degrees of cultural legitimacy. It is not only about stealing; it can also relate to the abuse of power in decision-making processes. It is a form of behavior that deviates from ethics, morality, tradition, law and civic virtue (NKWOCHA, 2009). Corruption is the act of doing something with intent to give some advantage inconsistent with official duty and the rights of others; an official use of a station or office to procure some benefits either personally or for someone else, contrary to the rights of others (GARNER, 2009). It is a behavior which deviates from the normal duties of public rule because of private regarding, pecuniary or status gain, or violates rules against the exercise of private-regarding influence. These include bribery, nepotism and misappropriation (NYE, 1967).

"Corruption has unfortunately become an endemic phenomenon with negative consequences on all aspects of Nigeria's national life. Corrupt practices are wide spread and causing serious damages to Nigeria's economy and image... Recently, Nigeria was rated number 19 among the poorest nations of the world, $7^{\text {th }}$ out of 160 countries considered to be most corrupt nations" (WAMAKKO, 2011, p. xvii-xviii). "The corrupt man is everywhere, the man on the street, the man next door, the man in the church or mosque, the man in the market or the departmental store, the policeman on beat patrol and the soldier at the check point" (OKADIGBO, 1987, p. 137). Chuta (2004) identified the various faces of corruption to include corner cutting, sensuality, immorality, cultural aberration, betrayal of trust and confidence, abusive/ misuse of power/office, favoritism/selfishness, extortion, bribery, dishonesty/financial deceit, piracy, substandard products, cheating, forgery/falsification, blackmail and sycophancy.

"The fact that no significant change has been reflected in the attitude of the average Nigerian towards corruption is irksome" (CHUTA, 2012, p. 246). The revelations in the Business Day of Monday $5^{\text {th }}$ December, 2011 about the 'moderate' sums of between $\$ 4$ billion and $\$ 8$ billion stolen from the country's coffers annually, and without a single politician serving a prison sentence for corruption, are glaring indicators on the one hand of the level of graft and on the other hand, the shabbiness 
DOI: 10.14807/ijmp.v5i3.198

and weakness in government's style of handling the issue of corruption in the country (CHUTA, 2012, p. 246). It is no more news that many prominent Nigerians are presently arraigned in court for corruption charges. An attempt would be made below, to present a multi-dimensional account of the phases of corruption in Nigeria.

\section{THE NATURE OF CORRUPTION IN NIGERIA}

Corruption in Nigeria has a long history, the only problem was that in traditional Nigerian society, its scope and dimensions were largely minimal because of the high ethical standard amongst the populace. Gradually, the rise of colonialism began to entrench corruption in the society through the deposition of legitimate rulers and replacing them with 'criminals' simply because they were imperial collaborators. "The post of Obas, Obis, Emirs and Amayanabos constituted the greatest anachronisms in the Nigerian society of 1965. The natural rulers were useful instruments of corruption and compromise, first under the British and later under the Nigerian politicians... they served as conduit to pass bribe to the people in order to miscarry social justice" (ADEWALE, 1981, p. 45) and "by the end of 1965, the politicians had earned almost universal contempt for their corruption, profligacy and lack of real concern for those they ruled and who had elected them" (CROWDER, 1962, p. 260).

Adamolekun (1985, p. 105) has stated that "the actions of the government over which Alhaji Shagari presided contradicted everything that was ethical and the moral tone of the society was at its lowest level ever". Unfortunately, the everlasting lesson which General Buhari sought to teach the corrupt political class collapsed like a castle of sand (CHUTA, 2004). "The Babangida years are historic because they marked the beginning of the institutionalization of authoritarianism, intensification of prebandist tendencies, patronage and corruption within the state apparatuses" (ABUBAKAR, 1997, p. 99).

"The phenomenon of massive corruption and its institutionalization as a key element of statecraft ... goes far back in Nigeria's history (and) was a major excuse for the overthrow of the First Republic and ... of Gowon's regime.... Both Shagari's regime, Buhari's, Babangida's an Abacha's regimes have also been indicated regarding massive looting of public resources (ASUU, 2002, p. 19). 
DOI: 10.14807/ijmp.v5i3.198

A journalist in an article titled "A Country of Low Expectations" (ONUMAH, 2011, p. 18-19) argued that in Nigeria, the police whose job is to protect lives as well as maintain law and order have ceased to maintain law and order. Each time we come in contact with a policeman or woman, we expect him or her to do the very opposite. Even in the midst of national insecurity, the greater percentage of our policemen are either keeping guard for our ubiquitous "big men" or accompanying "madam" to the market or hair salon. This is Nigeria and that's what the police is expected to do. In Nigeria, we see public service not as an opportunity to serve, but God's blessing.

So we expect public servants to make the best use of their God-given opportunity. It is not surprising, therefore, that public officers (elected officials and civil servants, including the military and police) are some of the wealthiest people in the country. Once you are in power, you and your family are expected to be above the law. Our leaders, so-called, all have lives outside Nigeria. It is no longer news. Nigeria is just the place to make your money. You are expected to go outside to spend it.

The Nigerian oil sector has become deeply immersed in the ocean of corruption that is flowing across the country. However, the recent development and findings from the House of Representative Ad-hoc Committee, headed by Farouk Lawan, which investigated the petroleum subsidy implementation, revealed that the subsidy regime has become a violent drain-pipe on the national treasury and a source of "cheap" riches for some Nigerians and their foreign imperial collaborators. Presenting the report on the floor of the House, the committee said, as at present constituted, Nigerians would never get value for money from the Nigerian National Petroleum Corporation (NNPC) and therefore proposed that it be unbundled. The salient aspects of the report included its recommendation of the refund of N1.067 trillion to the federal purse. The NNPC's share of this money is N310, 414,963,613 for kerosene subsidy (ANI; OKORO, 2012, p. 55). It gave the breakdown simply as:

- NNPC (above Petroleum Products Pricing Regulatory Agency \{PPPRA\} recommendations) - N285,098,000.00

- NNPC (self discount) - N108,648,000,000.00 
DOI: 10.14807/ijmp.v5i3.198

- Marketers (total violations of Petroleum Support Fund (PSF) N8,664,352,554

- Companies that refused to appear before the panel - N41,936,140005.31 and

- PPPRA's excess payment to self - N312,279,000,000 bringing the total money stolen by the agencies and others to N1,067,040,466,171.31. 00 (JIMOH; DAKA, 2012, p. 1).

The corruption scandal in the Nigerian oil industry is beyond what could be described in the pages of an article; it is complex, it is compound; it is multidimensional; it has caught-up the law-makers investigating it and presented the government as presently incapacitated in handling it. "The Otedola-Farouk scandal remains an open sore that will not get healed until and unless either or both the dramatis personae is or are prosecuted forthwith. That scandal makes a mockery of all claims that there is a war against corruption in Nigeria. The police have shown gross incompetence in handling the matter" (ATURU, 2012, p. 20).

The theft of Nigeria's oil is a crisis of immense proportion, in short, an economic sabotage, evident in the high sophistication and connection of the thieves who reportedly have their own network of pipelines through which crude is siphoned on daily basis into waiting ships. It is a complex operation perpetrated by a wellorganized mafia, which government up to now has not mustered the will to stop. Clearly, the security contracts are not serving any useful purpose just as the military deployment in the area has made no difference. The Nuhu Ribadu-led committee's report that 10 per cent of the country's oil is stolen daily is a mere confirmation of an oil syndicate, thriving in the face of the country's Army, Navy, Air Force and other military capability (THE GUARDIAN, 2012, p. 14).

In addition, the main buyers of the 18,000 barrels of oil that thieves steal from Nigeria each day are organized criminal networks in the Balkans and refiners in Singapore. Dele Cole, a politician from the oil-rich Niger Delta, at the heart of Nigeria's two million barrel a day (bpd) industry, told Reuters that 90 percent of oil snatched was sold on world markets, based on estimates from oil firms and the ministry. Just 10 percent was refined locally by gangs operating in the creeks and swamps of the delta, he said. 
DOI: 10.14807/ijmp.v5i3.198

Oil companies say so called 'bunkering'- tapping into oil pipelines to steal the crude - and other forms of oil theft are on the rise in Nigeria, despite an amnesty that was meant to end a conflict there in 2009 over the distribution of oil wealth. International theft is diverting huge quantities and the sophistication of the exercise from breaching the pipeline, to having barges, to knowing when ships are at the port, to being paid- is a major concern. Unfortunately, Nigeria relies on oil for more than 95 percent of government revenues. The figure of 180,000 bpd stolen comes from the upper end of an estimate by Shell, the biggest operator in the country, which frequently complains about the practice. Some estimates go as high as 25 percent of oil revenue (THE NATION, 2012, p. 5).

The oil companies have realized they are working for these bunkers and the government is also losing revenues to them. Finance Minister, Ngozi Okonjo-Iweala said in May 2012 that the government lost a fifth of its oil revenues to theft in April (THE NATION, 2012, p. 5).

Cole said much of the oil sold had been traced to criminal networks in the Balkans, especially Ukraine, Serbia and Bulgaria, better known for things like cigarette smuggling or trafficking sex workers. On the evidence we have, the Balkan mafia organizations are well represented in Nigeria... You can't chase these guys easily. They are as slippery as the proverbial eel. Singapore, the world's top refiner, was also taking a large chunk. He urged Nigeria to confront Singaporean authorities (THE NATION, 2012, p. 5).

The late President Musa Yar'Adua has stated that corruption is pervasive in our universities (UMARU, 2008). The story about the practice of demanding \#53, 000.00 from every candidate who sought to make his or her admission a sure bet in Institute of Management and Technology, Enugu can simply be described as an example of stinking admission culture across many Nigerian tertiary institutions (The Starlite,2008).

It is not news that some Nigerian lecturers demand money, sex etc. from students in order to pass them in their exams. During the one-day conference organized recently by the Obafemi Awolowo University Alumni Association, Lagos Branch; Austin Tam-George while discussing the theme "Positioning Nigerian University System for National Development" stated that "I teach in universities 
DOI: 10.14807/ijmp.v5i3.198

where, with all due respect, I worked with colleagues, who should probably be farmers, fishermen, but they end up in classrooms as lecturers and they demand sex and money from students before they award degrees" (OTTI, 2012, p. 31).

Austin Tam-George pointed-out the education-link to the national corruption in the country as he went on to argue that "one cannot solve a problem except there is a proper diagnosis, understanding of where the problem lies". He decried the poor quality of graduates in the country, saying that Nigerian students usually displayed the highest desperation for certificates, most often at the expense of the required skills. "We emphasise schooling and certificates to such an extent that out of the 18 years I have spent in teaching, both in Nigeria and abroad, I have never seen the level of desperation I see these days. Students want to get JAMB scores at all cost. I have right before me now the dissertations of PhD students and I can't imagine that doctoral candidates can be writing what they are presenting. Let's not make any mistake about this: we are in the middle of a major national disaster" (OTTI, 2012, p. 31).

Recently, a senior lecturer in the University of Benin was arrested for criminally collecting \#100,000 security-marked money from a student to change her course of study from English Language to Law. The arrest led to the discovery of a syndicate group that specializes in the extortion of money from students in the institution. Furthermore, a search in the lecturer's office by the university security personnel was said to have led to the discovery of a list of eighteen students, including the female student, who paid $\# 100,000.00$. Each for the purpose watering and influencing their change of course. When contacted, the Public Relations Officer of the University, Harrison Osarenren confirmed the incident, saying "with the arrest, we will try and rid the system of bad eggs" (OSAUZO, 2013, p. 9).

\begin{abstract}
When will the certificates and degrees that universities award on the basis of having been found worthy in learning and character begin to live up to the highest level of the content of its intentions? What character could such group of lecturers, impact to our students when some lecturers engage in sexual harassment, immorality and corruption? Lecturers supervising students' projects demand between $\# 250,000.00$ and over $\# 500,000.00$ from their students before their final year projects could be accepted. There are reports of swapping of grades and awarding of grades, and even whole degrees, to students that do not appear in the examination hall (CHUTA, 2012, p. 250).
\end{abstract}

Similarly, the former Vice-Chancellor of the Micheal Okpara University of Agriculture, Umudike, Prof. Ikenna Onyido, has blamed the rot in the university 
DOI: 10.14807/ijmp.v5i3.198

system on the decline "on the lack of 'value-based education' lamenting that 'universities in the country not only offer admission to students with questionable character, but also award degrees and diplomas to those not worthy in character and learning".

Onyido, who was the guest lecturer at a lecture organized by the Academic Staff Union of Universities (ASUU), Calabar Zone in honour of Prof. Ukachukwu Awuzie regretted that "the university culture is being watered-down by the importation and domestication of some toxic values from the larger society" (OKORO, 2012, p. $37)$.

However, for details of how some lecturers and some of their students are caught-up in the web of 'cash-for-marks' see Asiegbu's inaugural lecture (ASIEGBU, 2000). He delivered his historic paper using a metaphor thus: "let me now introduce this lecture more directly, by using the metaphor of an air flight... the name of your flight on this trip is scientific history flight... (while) our proposed destination on this trip is towards a sustainable Nigerian polity. The point of our departure on this flight is the Nigerian nation today" (ASIEGBU, 2000, p. 3-5).

He described how corruption is everywhere in the Nigerian state. The question is can any truthful Nigerian deny the ugly truth that Asiegbu and others have shown are people are still showing how Nigeria is almost intrinsically corrupt (ANI, 2011, p. 273).

Recently, on November, $12^{\text {th }} 2012$, the absence of Judges at the Court of Appeal, Lagos stalled the hearing of the appeal by the former Director General of the Nigerian Stock Exchange (NSE) Prof. Ndidi Okereke-Onyiuke. "The prosecutor accused her of stealing the money from the Stock Exchange (NSE)" (JIBUEZE, 2012, p. 7).

In 2008, it was reported that the former Governor of Adamawa State, Murtala Nyako and his then Deputy quizzed the state treasury through over inflation of contracts and projects in the state leading to the embezzlement of \#6.9 billion (DAILY SUN, 2008).

There are other Governors that have been probed and those still being probed. Names like Governor Chimaroke Nnamani of Enugu State, Governor Orji Uzor Kalu of Abia State, Governor Diepriyie Alamisia of Bayelsa State, Governor 
DOI: 10.14807/ijmp.v5i3.198

James Ibori of Delta State have at one time or the order passed through the corridors of the anti-graft agencies for financial related crimes.

Furthermore, the President Nigerian Institute of Quantity Surveyors, Agele Alufohai has stated that people who engage in corrupt practices are not as stupid as we think - they often have to avoid using quantity surveyors to enable them impose excessive costs on their employers - either the government or private firms and the public. He said that quantity surveyors live in Nigeria, a country with significant corruption problems.

"So let me say there may be some quantity surveyors who have found a way to cut corners... In my opinion, we leave too much room open for corruption in our system, so because many people are engaged in it. It's more difficult to catch and punish people. It's at a level in which it is a kind of socially acceptable thing" (UWAEGBULAM, 2012, p. 46).

Extensive government control and regulation of economic resources provide ample opportunity for illegality and corruption. Unfortunately, entrenched political elite dominates and exploits economic opportunities, manipulating relatively scarce and valuable political opportunities in return for personal gains (UNDP, 1999, p. 8).

Between 1999 and 2008 the political elite and corrupt government officials illegally took away billions of dollars of public money and stashed in foreign banks. In 1999 , the figure was $\$ 2,011.5$ million; in 2000 it was $\$ 6,335.8$ million; 2001 was $\$ 5,463.5$ million; in 2002 it was $\$ 5,135.4$ million; 2003 was $\$ 9,750.6$ million; in 2004 it was $\$ 14,990.8$ million; 2005 was $\$ 18,662.7$ million; in 2006 it was $\$ 23,217.4$ million; while it was $\$ 34,620.0$ million in 2007 and $\$ 51,694.6$ million in 2008 (AKINYEMI, 2010, p. 18).

The situation was such that Olusegun Obasanjo whose eight year tenure as president was characterized by profligacy only comparable to those of the military in the mid - 1980s and early 1990s, lamented that his successors had, as at late 2011, squandered over $\$ 103$ billion, which his administration had left behind in government coffers (DAILY INDEPENDENT, 2011, p. 1).

The increasing attempts by some Nigerians to smuggle huge sums of money outside the country through the nation's airports have added a worrisome new dimension to the problem of corruption in the country. The attempts to smuggle 
DOI: $10.14807 /$ ijmp.v5i3.198

money outside the country without formally declaring it to the appropriate authorities at the airports suggest that these are questionable funds that the couriers could not take out through the legitimate process for international money transfer. The origin and the uses to which such funds are to be applied are suspect, hence the need to stop movement of the sums, to verify their source and ensure that they are not stolen public funds.

This is because there is provision for travelers to take reasonable sums of money outside the country, as they are only required to declare the money at the Customs desk in the airports. However, the huge sums continuously intercepted and the failure of the travelers to declare the money makes them to be held as possible proceeds of corruption (DAILY SUN, 2012, p. 18).

\section{WATCHDOG INSTITUTIONS}

It is worthy to note that part of the ideas presented on the watchdog institution, which are institutional bodies that are meant to check-mate corruption in the country were advanced analysis from Nkwocha (2009, p. 6-10).

i. The Code of Conduct Bureau and Tribunal Act had the mandate to establish and maintain a high standard of public morality in the conduct of government business and to ensure that the actions and behavior of public officers confirm to the highest standard of public morality and accountability. Consequently, Section 3, part 1 of the Third Schedule to the 1999 Constitution of the Federal Republic of Nigeria has provided an enabling legal environment for the Bureau to:

a. Receive declarations by public officers under paragraph 12 of part 1 of the Fifth Schedule to the Constitution;

b. Examine the declarations in accordance with the requirements of the Code of Conduct or any Law;

c. Retain custody of such declarations and make them available for inspection by any citizen of Nigeria on such terms and conditions as the National Assembly may prescribe;

d. Ensure compliance with and where appropriate, enforce the provisions of the Code of Conduct or any law relating thereto; 
DOI: 10.14807/ijmp.v5i3.198

e. Receive complaints about non-compliance with or breach of the provisions of the Code of Conduct or any law in relation thereto,

f. Investigate the complaints and, where appropriate, refer such matters to the code of conduct tribunal;

g. Appoint, promote, dismiss and exercise disciplinary control over the staff of the Code of Conduct Bureau in accordance with the provisions of an Act of the National Assembly enacted on that behalf; and

h. Carry out such other functions as may be conferred upon it by the National Assembly.

ii. The Economic and Financial Crimes Commission (EFCC) was created in December, 2002 through an Act of the National Assembly. The Commission began operating in April 2003, when its Boards was inaugurated. It is charged with the following responsibilities:

a. Investigation of all financial crimes such as Advance fee Fraud (otherwise known as 419), money fraud, counterfeiting, illegal cash transfers, future market fraud, fraudulent encashment or fraudulent diversion of funds, contract scam, forgery of financial instruments, issuance of dud cheques.

b. Coordination and enforcement of all economic and financial crimes law, enforcement functions conferred on any other person or authority.

c. Adoption of measures to identify, freeze, confiscate or seize proceeds derived from terrorist activities, economic and financial crimes related offences or the properties, the value of which correspond to such proceeds.

d. Facilitation and rapid exchange of scientific and technical information as well as the conduct of operations geared towards the eradication of economic and financial crimes.

e. Determination of the extent of financial loss and such other losses by government, private individuals or organizations. 
DOI: 10.14807/ijmp.v5i3.198

f. Collaboration with government bodies within and outside Nigeria in carrying-out its functions wholly or in part analogous with those of the commission.

The EFCC has being progressively working to attain their institutional destiny. It could be recalled that "the Economic and Financial Crimes Commission (EFCC), recently confirmed its interception of cash amounting to \#15.5 billion at the airport in the first eleven months of 2012, said the sum represents illegitimate cash being taken out of the country. EFCC Chairman, Ibrahim Lamorde, at the 2012 International AntiCorruption Day celebration, said \#14 billion was intercepted between January and August this year, 2012 while the Special Task Team, a joint patrol by operatives of EFCC and the Nigerian Customs Service, seized another \$9 million (about \#1.5 billion) between August and October, 2012. In one instance, a man was arrested with $\$ 7$ million cash at the airport" (DAILY SUN, 2012, p. 18).

Again, on $26^{\text {th }}$ November, 2012, "Mamman Nasir Ali, son of former People's Democratic Party Chairman, Ahmadu Ali and three others were arraigned by the Economic and Financial Crimes Commission (EFCC) before an Ikeja High Court for alleged \#4.4 billion fuel subsidy fraud" (NWANNEKANMA; AYOBAMI-OJO, 2012, p. 3).

History would teach that "the conviction of James Ibori, former Governor of Delta, in April 2012, by a British Court, to a 13 years term of imprisonment, for involvement in a $\$ 250$ million fraud of Delta State funds, is a case in point. Initially, the Nigerian judiciary had found Ibori innocent of a 170-count charge of fraud and money laundry brought against him by the EFCC" (CHUTA, 2012, p. 259). This brings to question the soundness of judgments passed by the Nigerian judiciary, especially on issues of corruption and the embezzlement of public fund.

\section{iii. The Independent Corrupt Practice and Other Related Offences} Commission The commission shall be a body corporate with perpetual succession and a common seal and may sue as well as may be sued in its corporate name. The commission shall consist of a chairman and twelve (12) other members, two of whom come from each of the six geo-political zones:

a. A retired police officer not below the rank of commissioner of police;

b. A legal practitioner with at least 10 years post-call experience; 
DOI: 10.14807/ijmp.v5i3.198

c. A retired judge of a superior court of record;

d. A retired public servant not below the rank of a director;

e. A youth not being less 21 or more than 30 years of age at the time of his or her appointment;

f. A chartered accountant.

The Mandate of the Commission

1. Where reasonable ground exist for suspecting that any person has conspired to commit or has attempted to commit or has committed an offence under this Act or any other law prohibiting corruption to receive and investigate any report of the conspiracy to commit, attempt to commit or the Commission of such offence and in appropriate cases the offenders.

2. To examine the practices, systems and procedures of public bodies and where in the opinion of the Commission, such practices, systems or procedures aid or facilitate fraud or corruption, to direct and supervise a review.

3. To instruct, advice and assist any officer, agency or parastatal on ways by which fraud or corruption may be eliminated or minimized by such officer, agency or parastatals.

4. To advice heads of public bodies of changes in practices, systems or procedures compatible with the effective discharge of the public bodies as the commission thinks fit to reduce the likelihood or incidence or bribery, corruption and related offences.

5. To educate the public on and against bribery, corruption and related offences.

6. To enlist and foster public support in combating corruption.

Despite these bodies put in place by the country to fight corruption, it is obvious that their impact is not maximally or perfectly checking corruption so far. The reason is not farfetched; exploring all the various forms of corruption in any country may be close to an impossible task as different countries, societies, institutions, groups etc. often have their peculiar cases and forms in which corruption manifests. 
DOI: 10.14807/ijmp.v5i3.198

To make matters worse, the judiciary that should pass the final sentence on corrupttendencies and their sons and daughters of destruction are increasingly caught-up in the web of the Nigerian factor or corruption culture that is ravaging the whole country. "Our judges have not shown any enthusiasm in joining the anti-graft war, and many of them have, in fact, become obstacle to the war. They do not hesitate to issue injunctions against the EFCC, stopping it from the arrest and investigation of culprits" (OKUROUNMU, 2008).

It is also on record that several tribunal judges had been dismissed over bribery scandal during elections in some states in the past years. Another scandal took place in Zanfara State, where Justice Musa Anka, a High Court judge, was suspended for receiving bribe to deliver judgment (CHUTA, 2012, p. 255).

The pattern of corruption in the judiciary is characterized by gratification in which a judiciary staff in particular and many Nigerian civil servants could say but you will know that if you want your file to move, you had better do something. Otherwise, they will just keep telling you it is being attended to, whereas nothing is being attended to. Even if you offer them something, they will say, I didn't ask him. He was the one who gave me (ONOKOYA, 2008).

\section{CORRUPTION, SOCIAL VIOLENCE AND THE COLLAPSE OF ETHICAL CULTURE}

Corruption, according to Obasanjo (1999) has become a full-blown cancer in Nigeria. "Perhaps, in pursuant of our individual successes, we have inadvertently become too obsessed about our own self-interests that we forget the foundation that holds us up and we have been reaping too much from where we did not sow; perhaps we don't even see the need to sow" (JODA, 2011, p. 22).

According to Ribadu (2007:4), poverty at all levels of governance: a culture of impunity, which translates to an insatiable lust for luxury and waste; veneration of illicit wealth and primitive accumulation; poor reward system and the sacrifice of competence; as well as the overbearing investment in sycophancy and cronyism in the garb of loyalty, are some of the explanations for corruption in Nigeria today.

Corruption is a matter of ordinary human psychology that those who have benefited immensely and who derive political power from fraud are morally, politically and otherwise too weakened and too compromised to deal ruthlessly with corruption. 
DOI: 10.14807/ijmp.v5i3.198

Unfortunately in Nigeria, morally and politically compromised leaders determine who is accused and punished and who is not, and this has created severe credibility problems and handicaps in the struggle to defeat the cancer of corruption. As a result of the anti-people policies of Nigeria's rulers in the successive coalitions they have formed as government, the crises of insecurity, poverty, corruption, decay of social services, and national disgrace in international circles have escalated (ASUU, 2005, p. 5).

It could be argued that the excessive corrupt leadership that have arisen in the country at one time or the other have over the time neglected the environmental impact analysis of the oil pollution in the Niger-Delta, leading to the rise of militancy and kidnapping in the area. Today, the negative wind of kidnapping has spread through-out the country.

The killings and resource loss caused by kidnapping in the country remained unimaginable. The level of bunkering in the Niger-Delta and the inherent social violence that the militants have unleashed with it remains unquantifiable. President Jonathan's threat the other day to cancel the \#5.6 billion pipeline security contracts awarded to some ex-militants is also instructive, as it brings to the fore, the futility of government's decisions and action regarding oil theft.

The multi-billion naira contract was awarded to Chief Government Ekpemupolo (alias Tompolo); whose company, Oil Facilities Surveillance Limited, got the biggest contract; Mr. Victor Ebikabowei (alias Boy Loaf), Alhaji Mujaheed AsariDokubo, Ateke tom, Prince Ipalibo Gagogo Farah and Soboma Jackrich. Controversial as the contracts were, it was thought to be the panacea to the increasing oil theft in the Niger Delta. But events have shown that despite the huge contracts, the menace has not stopped. Instead, oil thieves have increased in number and strength and have become more daring, with clear negative effect on the economy.

Oil production has fallen with resultant shortfall in revenue. Between 180,000 to 200,000 barrels of crude oil, an equivalent of Gabon's oil production, amounting to well over $\$ 120$ million, is believed stolen (THE GUARDIAN, 2012, p. 14). Greed and fraudulent intent on the part of some international businessmen who saw Nigeria as haven for dubious money remains progressive. Nigeria is seen as a gold mine to 
DOI: 10.14807/ijmp.v5i3.198

them compared with the paltry sums, some Nigerians made in the name of advance free fraud (NKWOCHA, 2009, p. 200).

Governor Babatunde Fashola of Lagos State in his extreme judgment of the multiplier effect of corruption in the Nigerian Ivory Towers "dropped a bomb-shell by claiming that the nation's education system has produced more frustrated youths leading to the rise of social vices" (DIKE; EGEKWU, 2012, p. 36).

The violent multiplier effect of the social vices remains immeasurable. Nigerian universities that should serve as the prime environment for the molding of behavior and inculcating social values in the present and future generations of Nigerian leaders have deepened in the discouragement of excellence and promotion of mediocrity (NIGERIAN TRIBUNE, 2009).

The issue of corruption in universities in the country does not end in "sorting" to obtain favor and wipe out deficiency, but also manifests within the university administration in the form of nepotism. In matters of promotion and recruitment of academic and non-academic staff, the criteria of place of origin and relationship with the authority take precedence over competence and merit (CHUTA, 2012, p. 250).

Organizational cultures with lack of work ethics and absence of public accountability and responsibility will foster corruption. If work ethics are available, these may be flouted willy-nilly for personal gain leading to ethnic and cultural minorities perceiving themselves as being disadvantaged, thus their resorting to corruption to secure services from public administration. Research reveals that some service departments desperately need self-cleansing in this regard (NKWOCHA, 2009, p. 81).

"Paradoxically, immorality in public practice has created porosity for corrupt practices in this nation. People don't seem to execute their duties with any sense of morality... Perhaps, prolonged infiltration in immoral and unethical habits in the discharge of our duties and responsibilities has apparently jeopardized our collective development (JODA, 2011, p. 22-23).

"All over the land, you see our girls going into prostitution and our youths wallowing in joblessness despite our abundant resources. This is because there are many people in government who are not supposed to be there. They loot public treasury with impunity and allow the generality of the people to suffer" (ADEYEMI, 
2010, p. 34). It is unimaginable that unemployed Nigerians are requested in many quarters to bribe or rob the palm of the formal and informal agents of one employing firm, if they must make it to get their names shortlisted or even employed.

\begin{abstract}
Details of the graded amount routinely requested from applicants are as follows: the demand for between $\# 120,000.00$ and $\# 150,000.00$ is for graduate applicants; between $\# 70.000 .00$ and $\# 100,000.00$ is for National Certificate in Education and National Diploma, while between \#50,000.00 and $\# 60,000.00$ is for holders of General Certificate in Education. Less than one month following this disclosure by the Daily Sun, the August 5, 2008 edition of This Day came up with the story of an alleged collection of the sum of \#22 million from applicants for jobs with the Nigerian Prison Service (NPS). Some of the applicants were said to have given up to \#150,000.00 each, while some others paid \#240,000.00. In fact, one of the lady applicants petitioned the Independent Corrupt Practices and other Related Offences Commission (ICPC), alleging that the sum of \#500,000.00 was collected from her by officials of the Nigeria Prison Service and lamented that neither the job had been given to her nor her money returned to her (CHUTA, 2012, p. 248-249).
\end{abstract}

Moreover, "our elected leaders have ... not proved [to be] good students of the mistakes of the era of military dictatorship. They have continued to plunder the nation's treasuries; they have continued from where the military left off and have taken corruption beyond the imagination of even the most corrupt of Nigeria's past military rulers. The result is that $\ldots$ years after attaining independence, Nigeria is still languishing in the abyss of underdevelopment where basic infrastructures are inadequate, in some cases nonexistent" (ABU, 2003, p. 9).

"Today, Nigeria is in the grips of vicious elite, which continues to facilitate the plunder of her resources for the benefit of the same colonial metropolitan elite. The Nigerian elite are more than satisfied with the crumbs which drop from the table of the capitalist class in Europe and North America, and they are happy as long as a gulf of poverty separates them from the downtrodden" (PRATT, 2011, p. xiii-xiv).

The decay in the moral base of many Nigerians is obviously an underpinning factor for the growth of corruption in this country. The absence of morally sound behaviors even among some leaders fuelled many forms of unethical practices especially corruption. When there is moral decadence in a society, people become prone to compromises.

Once you compromise your values for greedy interests, you ultimately become prone to corrupt attitudes and the passion for it transcends beyond just taking bribes and stealing. One become even more entrenched in a cycle of deadly businesses like human trafficking, drug trafficking, robbery, violence and ritual sacrifice of human 
DOI: 10.14807/ijmp.v5i3.198

being beings for protection, money and power (JODA, 2011, p. 21-22). "It is clear to all now that the war against corruption has completely lost steam. What many of us do not understand is why governments and their functionaries still insult us by mouthing their so-called zero-tolerance for corruption. The correct position is that our governments at all levels now have zero-tolerance for anti-corruption war" (ATURU, 2012, p. 20).

\section{RECOMMENDATIONS}

Corruption is an immoral and unpardonable act against society and punishable by God" (CHUTA, 2012, p. 37). Abdulrazak Zaki, member House of Representatives' Committee on Federal Road Maintenance Agency (FERMA) has stated that "to me, the so-called fight against corruption by the Executive is just a farce because they give cover to corruption" (ANOFI, 2012, p. 52).

The position of Zaki is not just in agreement with my perception of the government's window-dressing culture of anti-corruption but also a widespread belief amongst Nigerians. Tell and Ernesto (2003) has called for controlling corruption or cure through high wages, while others called for anti-corruption assistance (TISNE; SMILOV, 2004).

My position is that high wages do not stop corruption as a man who is corrupt in orientation would continue with such culture irrespective of the amount paid to him or her. Musa (2009) has stated that only a revolution will save Nigeria at a time Adeyemi (2010) argued that corrupt officials should be shot, while for Ohakim (2008); corrupt leaders should be stoned to death, and Chief Ndueso Essien pointed -out that Nigeria should declare a state of emergency on corruption (EFFIONG, 2012).

"Fighting corruption in Nigeria often proves outstandingly difficult due to dissenting views. When corruption has become so routine that even seasoned thieves and corrupt god-fathers see its prevalence as normal, then a disaster is imminent. It is time the Nigeria State face reality and re-invents an ingenious way to stop this monster called corruption otherwise we would all be consumed by it" (NKWOCHA, 2009, p. 4-5).

The role of parents in fighting corruption cannot be neglected. They should be mindful of what they do in the presence of their children so that their children will not learn evil from them. They should mind the type of films they watch in the presence 
DOI: 10.14807/ijmp.v5i3.198

of their children or the type they allow their children watch because bad or corrupt films corrupts and ruins the mind. It is agreed that human beings learn from imitation and such, after watching those corrupt films, they would want to practice what they have watched and it could be destructive. Parents beware. (HEZEKIAH, 2012, p. 47).

"Today, there is growing evidence all over the world of young people contributing significantly to a more just world by taking action against social injustices such as corruption, organizing programs to support and promote political transparency and social responsibility at all levels. As the future leaders of this nation, youths have an enormous role to play in this fight. My assumption and primary concern is that if today's youths are not taught anti-corruption values, they will certainly grow up to be corrupt citizens and the same problems affecting the society as a result of corruption will remain unchanged" (WAZIRI, 2011, p. xv).

Again, the role of the legislatures both at the federal, state and local government is vital in the war against corruption. This is because the only amendment that would make sense is for the National Assembly to make crimes of corruption strict liability offences that would require the defendant show that she is innocent and justify how she came about her stupendous wealth and not for prosecution to prove that $s /$ he is guilty. The Constitution should also make it clear that there would be no interlocutory appeal in criminal cases. Without these safeguards, corruption cases will go on endlessly as we are already seeing with the oil subsidy scam. Reckless spending by states and the Federal Government needs to be checked urgently (ATURU, 2012, p. 20).

Reports of onslaught by a joint military force comprising the Army, Navy and Air Force against oil thieves in the Gulf of Guinea is a probable testimony that with the right resolve, government can contain the theft of crude oil in the country. Indeed, it is shameful that for years, crude oil is reportedly stolen with rampaging impunity, fuelling suspicion of a major collaboration between the thieves and highly placed officials. While the joint military operation may point to a determination by the President Goodluck Jonathan's administration not to be associated with the plundering of the nation's prime resources, government's seriousness to counter the menace will ultimately depend on the continuity of the military operations, as well as subsequent official action... Government, no doubt, should seize the momentum of public interest, partly generated by its own sponsored reports, to act decisively against oil thieves whose activities are telling on the prospects of the oil companies and exploration. The oil companies are not investing in new fields, thereby portending a clear and present danger to the country's oil future. In pursuing the responsible option of ending the theft, the Federal Government should enlist the support of countries and international agencies to explore the possibility of tracking the oil stolen from Nigeria through finger-printing of the oil to identify its origin. Government must be 
DOI: 10.14807/ijmp.v5i3.198

willing to act decisively and to curry the cooperation of the Nigerian National Petroleum Corporation (NNPC), the oil companies and if necessary, their foreign partners (THE GUARDIAN, 2012, p. 14).

\section{CONCLUSION}

Corruption is simply bad for the nation. To condone corruption is not only unpatriotic, but also irreligious for the adherents of African Traditional Religion, Christians and Muslims alike. No excuses is good enough for condoning the evil of corruption, be it on the basis of ethnicity, religion, sectional interest or in the offering of inducement in order to wield undue influence and pervert the truth.

Corruption thrives normally in societies where religious, traditional, ethical teaching and moral standards are weak and where punishment is lenient. These values that check corruption should be revived. Chiefs and religious leaders have a critical role to play in the resuscitation of ethical values in their subjects and congregations. Parents must learn not only to teach their children high moral standards but to maintain a high standard of moral consciousness in their everyday lives. Each family needs to enthrone a micro-ethical culture that would be synonymous to the family name.

Again, the institutions of higher learning are vital in the roadmap to check the increasing culture of corruption amongst Nigerians. There is need for students of higher institutions to be studious and stop bribing their lecturers. On the order hand, the lecturers should stand-up, frown-at and punish students that proactively lure the lecturers into act of bribery for marks. The civic education, social studies and religious studies curriculum of Nigerian schools and institutions of higher learning needs to be expanded in order to promote the rise sound culture of facilitating and indoctrinating the learners into anti-corruption dispositions.

Finally, combating corruption should be thought as more than simply weedingout crooked government officials. Such an approach has been implemented in many countries and has proven to be unsuccessful in terms of reducing the extent of corruption. Corruption is a symptom of underlying problems, not the problem itself. Therefore, the trends that sustain it should be addressed. These problems include opaque regulations, weak enforcement mechanism, and barriers to business, inefficient government agencies, absence of a public dialogue on corruption, excessive discretionary powers in the hands of public officials and lack of checks and 
DOI: 10.14807/ijmp.v5i3.198

balances. It is for the reason of institutional bottlenecks to the anti-graft agencies that the immediate past Chairman of the Economic and Financial Crimes Commission (EFCC), Farida Waziri and some other Nigerians, have called for the establishment of Special Courts to deal with special cases of corruption within limited time.

I strongly believe that this call has become highly critical today on the grounds that the anti-corruption agencies in the country are losing relevance as a result of their consistent resort to protocols and procedures in their feeble attempts to confront a powerful culture like corruption. The continued delays in the investigation, prosecution and punishment in corruption cases in Nigerian law courts have led to many indicted corrupt officials hiding under the loophole created by the delay in the rule of law. Simply, corruption is an institutional problem and the institutions that allow for sustainability of corruption should be reformed.

There is need for honesty, integrity, promise-keeping, fidelity, fairness, caring, respect, responsibility, excellence and accountability as multi-dimensional ways of curbing corruption. Every Tom, Dick and Harry need to join hands in the war against corruption in Nigeria, irrespective of position in the social class, ethnic and religious affiliation.

\section{REFERENCES}

ABU, B. D. (2003) A Journey to Uncertain Future, Newswatch, October 5, p. 9.

ABUBAKAR, D. (1997) The Rise and Fall of the First and Second Republics in F. OKAFOR, U. (Ed.) New Strategies for Curbing Ethnic and Religious Conflicts in Nigeria, Enugu: Fourth Dimension, p. 99

ADAMOLEKUN, L. (1985) The Fall of the Second Republic, Ibadan: Spectrum Books Ltd.

ADEWALE, A. (1981) Why We Struck-The Story of the first Nigerian Coup, Ibadan: Evans Bros Ltd.

ADEYEMI, S. (2010) Corrupt Officials Should be Shot, Daily Sun, September 6, p. 34

AGBROKO, G. (2004) Corruption, Public Enemy, n. 1, p. 37 in CHUTA, S. C. (2004) Corruption in Nigeria, Nsukka: Afro-Orbis Publishing Co. Ltd

AKINYEMI, B. (2010) How to Tackle Corruption, The Nation, Tuesday, May 4, p. 18

ANI, K, J. (2011) Politics About Failed State in Nigeria: Dialectics on the Value of History to Nation Building Challenges, 1960-2010, Enugu: Firstbook, p. 273

ANI, K. J.; OKORO, S. I. (2012) Contemporary Demonstrations, Violence and the Challenge of Good Governance in Nigeria in A. B. C. Chiegboka, T. C. UtohEZEAJUGH, E. U.; IBEKWE, C. C.; NWOSU, N. C.; OGUNO, K. L.; NWADIALOR 
DOI: 10.14807/ijmp.v5i3.198

(Eds.) The Humanities and Good Governance, Nimo: Rex Charles \& Patrick Ltd, pp. 50-58.

ANOFI, D. (2012) Reps Blame FERMA, Contractor for State of \#300m Road Project, The Nation, Tuesday, October 23, p. 52

ASIEGBU, J. U. J. (2000) Clio Magistra Vitae: History and Nigeria's Societal Engineering, Inaugural Lecture Series, Port Harcourt: University of Port Harcourt Press, $7^{\text {th }}$ June

ASUU (2005) The Position of the Academic Staff Union of Universities (ASUU) on the Problem of Corruption and the National Dialogue in Nigeria, Issued by the National Executive Council (NEC) of ASUU, May, p. 2.

ASUU (2002) The State of the Nation, A publication of the Academic Staff Union of Universities (ASUU), March

ATURU, B. (2012) "We must Eschew Corruption, Greed and Waste", The Nation, Tuesday, November 13

CHUTA, S. C. (2012) Corruption in Nigeria: An Expose in C. K. Ikwuemesi (Ed.) Astride Memory and Desire: Peoples, Cultures and Development in Nigeria, Enugu: ABIC Books, pp. 245-262

CHUTA, S. C. (2004) Corruption in Nigeria, Nsukka: Afro-Orbis Publishing Co. Ltd CROWDER, M. (1962) The Story of Nigeria, London: Faber and Faber

DAILY INDEPENDENT (2011) Obasanjo Accuses Yar'Adua, Jonathan of Squandering \$103 billion, v. 10, n. 22179, Monday, November 21, p. 1.

DAILY SUN, (2012) Interception of \#15.5 bn at Airports, Tuesday 18, p. 18

DAILY SUN (2008) \#6.9 billion Fraud; Nyako, Deputy, others Quizzed, July 2.

EFFIONG, J. (2012) Nigeria Should Declare a State of Emergency on Corruption"Chief Ndueso Essien, Daily Sun, May 22

DIKE G.; EGEKWU, E. (2012) Our Education Breeds Frustrated Youths-Fashola, Daily Sun, Tuesday, October 9, p. 36

DI TELL, R.; ERNESTO, S. (2003) Controlling Corruption through High Wages, Global Corruption Report, Berlin: Transparency International, 2003

GARNER, B. A. (2009) (ed.), Black's Law Dictionary, $9^{\text {th }}$ edition, Minnesota: West Publishing Co.

HEZEKIAH, D. (2012) Inspiration: Bribery and Corruption (3), Weekend Champion, December 15, p.47

HODGES, A. (Ed.) (2001) Presidential Statement made by Olusegun Obasanjo in his swearing-in speech, May 29, 1999 in Women and Children Rights in Nigeria: A Wake-Up Call: Situation Assessment and Analysis, Abuja: National Planning Commission, p. 29.

JIBUEZE, J. (2012) Okereke-Onyiuke: Hearing in Appeal Stalled, The Nation, November 13, p. 7

JIMOH, A. M.; DAKA, T. (2012) How They Bleed Nigeria!, The Guardian, Thursday. April. 19, p. 1. 
JODA, T. H. (2011) Anti-Corruption Handbook for Nigerian Youths: A Fundamental Paradigm for Re-branding Education, Business, Politics and Public Administration in Nigeria, Lagos: Joyce Graphic Printers and Publishers, p. 22-23

MUSA, B. (2009) Only A Revolution will Save Nigeria, Daily Champion, October 2 NKWOCHA, M (2009) Systemic Corruption and Control, Jos: Bobb Morgan Ocha \& Co

NWANNEKANMA, B.; AYOBAMI-OJO,Y. (2012) Ali's Son, Others Re-Arraigned Over Subsidy Scam, The Guardian, Tuesday, November 27, p. 3

NYE, J. (1967) Corruption and Political Development: A Cost-Benefit Analysis, American Political Science Review, v. 16, n. 2, June

OHAKIM, I. (2008) Stone Corrupt Leaders, Daily Sun, December 5

OKADIGBO, C. (1987) Power and Leadership in Nigeria, Enugu: Fourth Dimensions

OKORO, J. (2012) Don Blames Decay in University Education on Lack of Moral Values, Daily Sun, Tuesday, October 9, p. 37

OKORO, J. (2012) Stop Bribing Lecturers, VC Warns Students, Daily Sun, Monday, November 26, 2012, p. 9

Onokoya, T. (2008) Corruption Still Persists in the Judiciary, Nigerian Compass, October 9 ,

ONUMAH, C. (2011) A Country of Low Expectations, August 2, in C. Onumah, Time to Reclaim Nigeria (Essays 2001-2011), Nigeria lies Prostrate Today because of the Actions, and Sometimes Inaction, of Nigerians, Abuja: African Centre for Media \& Information Literacy, 2011, p. 18-19

OSAUZO, T. (2013) Lecturer Caught in the Act... Collects Marked Money from Female Student, Daily Sun, Wednesday, January 9, p. 9

OTTI, S. (2012) How Lecturers Demand Sex, Money from Students: Revelations from the OAU Alumni Deliberations on Rot in Education Sector, Daily Sun, 9th October, p. 31.

PRATT K. JR. (2011) Introduction, in C. Onumah, Time to Reclaim Nigeria (Essays 2001-2011): Nigeria lies Prostrate Today because of the Actions, and Sometimes Inaction, of Nigerians, Abuja: African Centre for Media \& Information Literacy, pp. xiii-xiv

RIBADU, N. (2007) Interview, The Guardian, Sunday, August 19, p. 4

TISNE, M.; SMILOV D. (2004) From the Ground Up: Assessing the Record of Anticorruption Assistance in Southeastern Europe, Budapest: The Centre for Policy Studies, Central European University

THE GUARDIAN (2012) Editorial: The Worsening Crude Oil Theft, Tuesday, November 27, p. 14

THE NATION (2012) Balkans, Singapore top Buyers of Stolen Nigerian Oil, Tuesday, October 23, p. 5

THE STARLITE NEWSPAPER, (2008) IMT Enugu Stinks, July 7 
UMARU (2008) Corruption Pervasive in Our Universities, This Day, December 21 UNDP (1999) Fighting Corruption to Improve Governance, A publication of the United Nations Development Programme (UNDP), February, p. 8.

UWAEGBULAM, C. (2012) Property Interview: Corrupt Dealers avoid Quantity Surveyors, Says Alufohai, The Guardian, Monday, October 29, p. 46

WAMAKKO, A. M. (2011) Preface T. H. Joda, Anti-Corruption Handbook for Nigerian Youths: A Fundamental Paradigm for Re-branding Education, Business, Politics and Public Administration in Nigeria, Lagos: Joyce Graphic Printers and Publishers pp. xvii-xviii

WAZIRI, F. (2011) Forward in T. H. Joda, Anti-Corruption Handbook for Nigerian Youths: A Fundamental Paradigm for Re-branding Education, Business, Politics and Public Administration in Nigeria, Lagos: Joyce Graphic Printers and Publishers, p. xv 